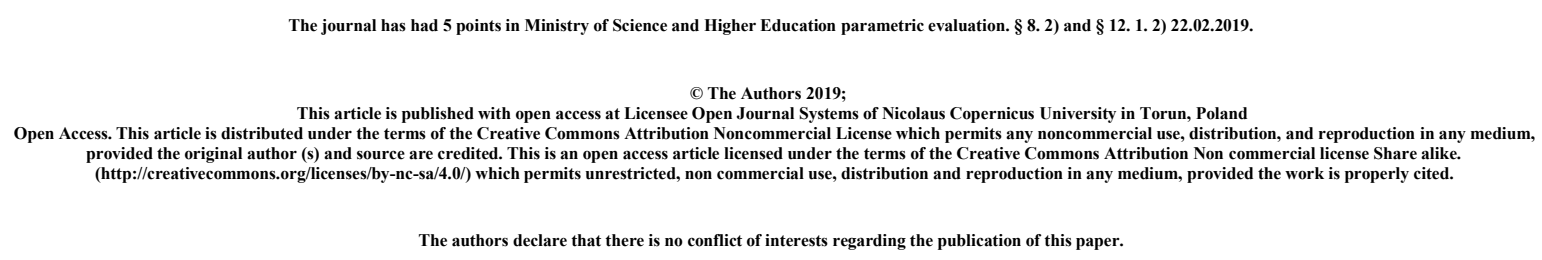

Received: 01.06.2019. Revised: 14.06.2019. Accepted: 24.06.2019.

\title{
CONCEPTUALIZATION OF THE PHENOMENON OF ECOLOGICAL VALUES AS A BASIC NOTION FOR PROFESSIONAL TRAINING OF FUTURE NATURAL SCIENCES TEACHERS
}

\author{
Valentyn Rohoza \\ Research fellow of the Department of Profile Education of the \\ Institute of Pedagogy of the National Academy of \\ Pedagogical Sciences of Ukraine \\ e-mail: rogozav@@ukr.net \\ ORCID ID: 0000-0002-9552-0310
}

\begin{abstract}
The article conceptualizes the phenomenon of "ecological values", which is the basis of educational and professional training of future teachers of natural sciences. The research focuses on identifying the system of values and their hierarchy in order to achieve at least two key results: 1) the formation of a higher level of a value sphere of future natural sciences teachers and improvement of the process of acquired values transfer; 2) improvement of learning outcomes (improvement in behavior, awareness, knowledge). Based on the extensive analysis of the scientific literature, the research suggests the meaningful characteristic of the formulated ecological values of the future natural sciences teachers. As a result, the research has considered the ecological values of future natural sciences teachers as an integrated value block in the system of their value orientations.
\end{abstract}

Key words: values, ecological values, future teachers, concept, professional training. 


\section{Introduction}

The leading scientists in the world are increasingly turning to the problems of the intrinsic value of nature in relation to the biotic diversity (Soule 1985, Rolston 1986, Callicott 1989, 2006). For many years, this topic has been of great importance for humanity, as evidenced by international declarations on environmental issues, in particular (UNEP, 21 Issues for the 21st Century 2012, UN Climate Action Summit 2019). This is about the socalled "conservation biology" theory, practical implementation of which can significantly prevent the destruction of nature and the emergence of many cataclysms connected with this destruction. One of the most important components of this theory is, in our opinion, the system of ecological values, the carriers of which should fully be future teachers of science. It is by forming a system of internal eco-values of teachers that we can expect its effective transfer to students and on this basis to achieve better conservation effects.

One of the dominant approaches postulates that the intrinsic value of nature is created on the basis of human evaluation (Callicott 1986, Elliot 1992), and this may mean that the ethical dimension of ecological values can have real outlines and be passed on from educators to trainees. Scientists also suggest certain classifications of such values, for instance, instrumental ecosystem values (different from M. Rokeach's classification), such as: cultural value, recreational value, medicinal value, spiritual value, transformational value, natural resource value, and ecosystem services value (Sandler 2012). Depending on the assessment, such subjective intrinsic values are more or less important for a person. However, for a large number of people, ecological values do not matter and this fact attracts the attention of teachers who are the carriers of the ideal ethical and value model of the society, which they represent. We agree with the opinion that such values are part of the ecological worldview of an individual, so their assimilation is an important prerequisite for successful development of sustainable development in general and may be an example of the attitude to the environment, especially for students (Kramarenko 2015). Therefore, this research deals with the topic of forming a system of ecological values of future natural sciences teachers.

It should be specially noted that in the process of solving the problem of conceptualization of the phenomenon of ecological values as a basic concept for professional training of future natural sciences teachers, we must remember that the modern system of higher education in Ukraine is undergoing a transition to the competency model of training, which is reflected in the Law of Ukraine "On Higher Education” dated July 1, 2014, № 1556VII. Therefore, in the process of professional training of future natural sciences teachers, it is necessary to organize the educational process in such a way that it will allow achieving the formation of a certain set of competencies (including axiological ones), which represent readiness to implement certain professional behavior. In this relation, the development of ecological values cannot be considered in separation from the development of value and ecological competencies. That is, there is a question of ensuring their development in the integrated educational process, and the emphasis should be not just on the development of certain competencies, but also on the readiness for their practical implementation, which ultimately is the direct and best confirmation of the acquisition of ecological values.

\section{Problem of Research and Research Focus}

This research focuses on two basic tasks: 1) to carry out theoretical conceptualization and practical interpretation of pedagogical conditions for the formation of ecological values of teachers of the corresponding profile; 2) to carry out the subject conceptualization of the phenomenon of ecological values as a basic concept for professional training of future natural sciences teachers. The tasks are interconnected concerning their content, but it is obvious that the solution of the first task is not possible without the meaningful solution of the second. For this reason, the research pays special attention to the issue of conceptualization of the 
phenomenon of ecological values, which should be finalized by the definition of "ecological values of natural sciences teachers". This definition should include the potential of humanistic principles of the personality-oriented approach and new axiological ideas of the value approach.

\section{Research Methodology}

In general, the methodological basis of this attempt to conceptualize the phenomenon of ecological values as a basic concept for professional training of future teachers of natural sciences are objectivist axiological concepts.

The following theoretical methods were used to solve the research problems:

study and analysis, synthesis, comparison, classification and generalization of information from philosophical, psychological and pedagogical literature, and methodological sources in the aspect of axiological issues in order to clarify key definitions and develop conceptual provisions;

systematization and generalization of the advanced pedagogical experience, normative documents, and modeling, on the basis of which the concept of professional and value orientations development of future natural sciences teachers in the course of professional training is substantiated;

analytical: historical and logical search aimed at studying the theoretical foundations of the research problem; empirical: pedagogical observation, conversation, interviews, ranking, discussion.

\section{Research Results}

After analyzing a significant amount of scientific literature on the problem, we have concluded that an important scientific position for substantiation the prospects of value education is the interpretation of the value system not only as a consequence of inherent human needs, but also as a result of "implementation" through social influences and values positive from the point of view of the society (Sosunova, Mamonova 2018, 153). Regarding the situation of professional training of future natural sciences teachers, it is of fundamental importance to ensure, so to speak, a moment of "meeting" and "immersion" in the system of ecological values, sanctioned not only by the society but also by the logic of environmental laws (Nature laws). Concerning the topic of the research relevance, it should be noted that modern scientific literature suggests different systems of ecological values (table 1). 


\section{Systems of ecological values}

\begin{tabular}{|c|c|c|}
\hline \# & Name & Content characteristics \\
\hline 1. & $\begin{array}{l}\text { According to the depth of social } \\
\text { perception (Kramarenko 2015) }\end{array}$ & $\begin{array}{l}\text { a) universal ecological values; } \\
\text { b) socio-natural ecological values (ecological-ethical, ecological- } \\
\text { humanistic and ecological-aesthetic values; socio-productive } \\
\text { ecologically oriented activity as a value); } \\
\text { c) personal-ecological values that have an individual character and } \\
\text { are formed due to the subjective ecological experience of a } \\
\text { person. }\end{array}$ \\
\hline 2. & $\begin{array}{l}\text { According to the level of } \\
\text { distribution } \\
\text { (Matviichuk 2014, 198-199) }\end{array}$ & $\begin{array}{l}\text { a) social ecological values (function in different social systems } \\
\text { and have manifestations in the public consciousness, depend on } \\
\text { the ecological-historical and socio-economic experience of a } \\
\text { society and are a set of ideas, images, norms and traditions that } \\
\text { regulate the relationship between people and nature); } \\
\text { b) group (professional) ecological values (regulate and direct } \\
\text { specific types of human activities within certain social systems, } \\
\text { such as: economics, politics, scientific and technical, and social } \\
\text { activities); } \\
\text { c) personal-ecological values (specific psychological formations } \\
\text { that reflect the goals, motives, ideals, attitudes and other } \\
\text { worldview characteristics of the human personality, which make } \\
\text { up the system of value orientation in the context of the } \\
\text { relationship with nature). }\end{array}$ \\
\hline 3. & $\begin{array}{l}\text { Integrated socio-ecological } \\
\text { values } \\
\text { (Sosunova, Mamonova 2018, } \\
\text { 154) }\end{array}$ & $\begin{array}{l}\text { a) individual (possibility of full realization of civil rights } \\
\text { regarding the condition of the environment; possibility of } \\
\text { participation in decision-making affecting the condition of the } \\
\text { environment; access to the system of ecological education and } \\
\text { upbringing; ecological design of personal and industrial space; } \\
\text { availability of reliable empirical information on practice and } \\
\text { consequences of interaction of the society with nature; } \\
\text { participation in nature management and environmental practice); } \\
\text { b) social (environmental safety (individuals and groups); } \\
\text { communicative opportunities for the formation and articulation of } \\
\text { public opinion on environmental issues; positive standards of } \\
\text { environmental morality; a decent quality of life that meets socio- } \\
\text { environmental requirements and norms). }\end{array}$ \\
\hline
\end{tabular}

This classification of ecological values serves as a theoretical basis for the conceptualization of the phenomenon of ecological values as a basic concept for professional training of future natural sciences teachers. At the same time, taking into account this system, as well as the development of the ethics of life by Albert Schweitzer (Schweitzer 1996), the concept of the noosphere by Volodymyr Vernadsky (Vernadsky 1989), the land ethic by Aldo Leopold (Leopold 1983), deep ecology by Arne Naess (Seed, Macy, Fleming, Naess 1994), ethics of responsibility by Jonas Hans (Hans 2001), concept of common world by Klaus Michael Meyer-Abich (Meyer-Abich 2004) and others, we consider it possible to single out such ecological values that are of fundamental importance in the context of professional training of future natural sciences teachers (table 2). 
Table 2.

\section{Fundamental ecological values for the professional training of future natural sciences teachers}

\begin{tabular}{|c|c|c|c|}
\hline$\#$ & Type of the value & $\begin{array}{c}\text { Purpose } \\
\end{array}$ & Practical use \\
\hline 1 & $\begin{array}{l}\text { the value of life in all its } \\
\text { manifestations }\end{array}$ & $\begin{array}{l}\text { acquiring knowledge about the } \\
\text { primacy of the value of life in } \\
\text { relation to other values }\end{array}$ & $\begin{array}{l}\text { formation of value-normative, } \\
\text { ethical-activity worldview }\end{array}$ \\
\hline 2 & nature itself as a value & $\begin{array}{l}\text { acquiring knowledge that nature } \\
\text { embodies goodness, truth and } \\
\text { beauty, which is also the basis for } \\
\text { recognizing its value }\end{array}$ & $\begin{array}{l}\text { formation of the ability to } \\
\text { reflect and self-assess } \\
\text { concerning the nature and } \\
\text { environmental knowledge in } \\
\text { professional activities }\end{array}$ \\
\hline 3 & $\begin{array}{l}\text { the value of harmony with } \\
\text { nature }\end{array}$ & $\begin{array}{l}\text { acquiring knowledge about the } \\
\text { relationship between human beings } \\
\text { and nature, society and nature }\end{array}$ & $\begin{array}{l}\text { formation of value-normative, } \\
\text { ethical-activity worldview }\end{array}$ \\
\hline 4 & $\begin{array}{l}\text { biocentrism as a responsibility } \\
\text { for the world of living beings }\end{array}$ & $\begin{array}{l}\text { formation of the belief in the } \\
\text { primacy of the interests of the } \\
\text { ecosphere over the interests of } \\
\text { human beings }\end{array}$ & $\begin{array}{l}\text { stimulation of efforts towards } \\
\text { self-realization and self- } \\
\text { development in the field of } \\
\text { modern ecological technologies }\end{array}$ \\
\hline 5 & $\begin{array}{l}\text { healthy environment as a } \\
\text { value }\end{array}$ & $\begin{array}{l}\text { acquiring knowledge that the values } \\
\text { of a healthy environment } \\
\text { correspond to the strategy and } \\
\text { content of human development and } \\
\text { humanity in general }\end{array}$ & $\begin{array}{l}\text { contribution to the formation of } \\
\text { the ability to carry out a set of } \\
\text { environmental actions, aimed at } \\
\text { transforming the surrounding } \\
\text { reality in terms of eco-centric } \\
\text { understanding of nature }\end{array}$ \\
\hline 6 & $\begin{array}{l}\text { the value of quality of life (in } \\
\text { ecological discourse) }\end{array}$ & $\begin{array}{l}\text { acquiring knowledge about the } \\
\text { fundamental nature of quality in } \\
\text { ecological life discourse for human } \\
\text { beings and society }\end{array}$ & $\begin{array}{l}\text { stimulation of efforts towards } \\
\text { self-realization and self- } \\
\text { development in the field of } \\
\text { modern ecological technologies }\end{array}$ \\
\hline 7 & $\begin{array}{l}\text { the value of ecological } \\
\text { knowledge }\end{array}$ & $\begin{array}{l}\text { formation of belief of urgency and } \\
\text { practical relevance of special } \\
\text { ecological training, certain eco- } \\
\text { competences }\end{array}$ & $\begin{array}{l}\text { formation of an established } \\
\text { need for } \text { professional } \\
\text { knowledge, skills, and abilities }\end{array}$ \\
\hline 8 & ecological image as a value & $\begin{array}{l}\text { acquiring knowledge about the } \\
\text { ecological image associated with } \\
\text { environmental } \\
\text { environmental rationality, and } \\
\text { minimization of environmental } \\
\text { risks }\end{array}$ & $\begin{array}{l}\text { contribution to the formation of } \\
\text { the ability to carry out a set of } \\
\text { environmental actions (in terms } \\
\text { of content), aimed at } \\
\text { transforming the surrounding } \\
\text { reality in terms of eco-centric } \\
\text { understanding of nature }\end{array}$ \\
\hline
\end{tabular}

* - author's own development

Singling out these environmental values has a theoretical and methodological basis. Initially, we start from the position indicated in the previous statement that values for us appear as a powerful source of behavioral motivation and a regulator of the activities of an individual and society. The second principle point for us is that values are an essential characteristic of a person, and their understanding is an integral condition of the movement to happiness and well-being, optimal position in public space. The third fundamental point for our study is that values have a social nature and their own meaning for the subject in the process of internalization. In the process of internalization, values, without losing their social orientation, form the value orientations of an individual, which are the determinants of life strategies and models of human behavior (including professional). Therefore, analyzing various value hierarchical systems, given that they are created on the basis of sometimes very 
different approaches and principles, we focus primarily on how value components of these systems:

- (1) can perform a regulatory function;

- (2) can characterize a personality in the context of the idea of harmonizing the relationship "Human being - Nature";

- (3) can act as eco-centric determinants of life strategies of the person on condition of their perception and transformation into value orientations.

Applying these criteria, we get a practical opportunity to identify those values that will be of a fundamental nature in the context of the formation of professional competencies of future natural science teachers.

The methodological basis of this attempt to conceptualize the phenomenon of ecological values as a basic concept for professional training of future natural sciences teachers is, as mentioned earlier, objectivist axiological concepts. Recognition within these concepts of the objective nature of values results in their systematization, hierarchy and existence of universal values. As the Dutch researcher Geert Hofstede once noted, values are interconnected, have a certain intensity and form systems of values or hierarchies. In this case, the scientist defines values as a general tendency to prefer a certain state of affairs to another (Hofstede, G. 1980). The analysis of value hierarchical systems and the consideration of universal values articulated by the philosophical and scientific community are essential within the framework of this research. This analysis of value hierarchical systems should be preceded by caution in the sense that today the axiological science has earned a significant number of them, at least a few dozen. There are obviously two explanations for this.

First, the significant number and substantive diversity of classifications is due to the pluralistic nature of the concept of "value" itself, which was mentioned before. In addition, values, having a "spiritual" objectivity, also carry in themselves a "material" objectivity, because they use as a source the content of feelings (Buhaiova 2009, 54). The scientific position of Max Scheler should also be mentioned. He singled out several types of values in connection with their essential carriers: personal values and subject values; own and others' values, values of acts and values of functions; values of reactions, values of persuasion, values of action, values of success, values of intention and values of a condition, values of the reasons, values of forms and values of relations, individual and collective values, independent and derivative values (Scheler 1994). The division proposed by Scheler clearly demonstrates the dualistic nature of values.

Secondly, such a dualism of the substantive content of values leads to their different interpretations, especially if we take into account the logical position that a human being "at some stage begins to actively develop own values and participate in the formation of group values or value orientations" (Matviichuk 2014, 180). At the same time, it is a kind of justification of our right to initiate and substantiate own system (classification) of ecological professionally significant values of future natural sciences teachers, which was presented above.

It should also be borne in mind that values may be different in their content and functionality, which already justifies the appropriateness of their particular typology and classification. In this regard, it is worth mentioning the division of values into two types, which was proposed by the American psychologist Milton Rokeach: 1) terminal (belief that certain ultimate goals of individual existence from a personal and social point of view are worthy of being pursued); 2) instrumental (the belief that a certain course of action is from a personal and public point of view the most acceptable in any situation) (Rockeach 1973). It is worth noting that the division of values proposed by Rokeach substantially echoes the approaches to the phenomenon of values proposed by another American researcher - Charles Morris, who divided values into "conscious values" (declarative) and "values in action" (basis 
of behavior) (Rohova 2010, 58). Starting from these considerations, we can suggest the prospect of singling out environmental values:

1) values of terminal-positional nature, which are the values of knowledge and ideas of a certain type (for example, the idea of the self-worth of nature, recognition of the value of harmony with nature), the perception of which positively characterizes an individual in the context of harmonization the relationship "Human being - Nature";

2) values of instrumental and behavioral nature (in particular, the value of activities to ensure a healthy environment, the value of activities to achieve quality life in the ecological sense), which can act as eco-centric determinants of life (including professional) behavior.

It should be noted that the ideas of Milton Rokeach and Charles Morris resonate, as we see it, with the ideas of the American psychologist Shalom Schwartz, who suggested the typology of values based on the criterion of their significance for an individual as principles of life or lifestyles that give a sense of satisfaction and happiness. It is significant that the researcher believes that the values described by him are universal for different types of cultures, because they fix the universality of value motivations of individual behavior. Therefore, as it is known, Schwartz divides the basic values into four motivational blocks: 1) values of Preservation (security, conformity, tradition), 2) values of Openness to change (independence, stimulation, hedonism), 3) values of Self-determination (universalism, benevolence), 4) values of Self-exaltation (power, achievement, hedonism) (Schwartz 1992). For the task of conceptualizing the phenomenon of ecological values as a basic concept for professional training of future natural sciences teachers, two Schwartz's blocks are fundamental: the values of preservation and the values of openness to change. Undoubtedly, the values of preservation agree with the value of harmony with nature, biocentrism as a responsibility for the world of living beings. Instead, the values of openness to change resonate with the value of environmental knowledge, as well as the value of environmental image.

When analyzing the classifications and typologies of values, it is necessary to mention the now classic value classification of the American researcher Ronald Inglehart, which is based on the hierarchy of needs of Abraham Maslow. Thus, Inglehart divided values into two main types: materialist values (predominance of material and physical security), which corresponded to the lower levels of Maslow's hierarchy, and post-materialist - higher levels (freedom, participation, self-expression, beauty) (Inglehart 1977). The studied by this research ecological values of future natural sciences teachers correlate both with the materialist dimension (the value of life in all its manifestations; a healthy environment as a value; the value of quality of life (in ecological discourse)) and with the post-materialist (biocentrism as a responsibility for the world of living beings; the value of ecological knowledge; ecological image as a value), which confirms their complex and systemic nature.

At the same time, it should be noted that Ronald Inglehart has been analyzing the trends of economic and technological development of society, as well as the processes of modernization and democratization for several decades (Inglehart 1997). The categories of such an analysis are two key bipolar dimensions of culture - survival/self-expression and traditional/secular-rational authority. Based on their own methodology, Ronald Inglehart and Wayne Baker, summarizing the results of three comprehensive studies of the World Values Survey (WVS: 1981-1982; 1990-1991 and 1995-1998), stated that in the global aspect, cultural changes are taking place in the direction of increasing the importance of the value of rationality, tolerance, trust and participation of citizens in the decision-making process in political and economic life. From our part, we should add that these periods are characterized by a trend of growing urgency of environmental issues, which led to the growing popularity of environmental ethics (care for the environment, environmental management, and public participation in decision-making on the environmental friendliness of certain production 
projects). Given this trend, the importance of environmental values for the society tends to increase. In addition, the analysis of the World Values Survey 2005-2007 confirmed that the global process of modernization and technological progress contributes to the growth of education in the society and, consequently, the spread of the values of self-expression (Inglehart, Welzel 2010), to which, in our opinion, it is reasonable to attribute such values as biocentrism, the value of ecological knowledge, and ecological image as a value.

Finally, in Ronald Inglehart's scientific works, there is another conceptual for our study position. In particular, traditionally, the classical concept of modernization is dominated by the theory of rational choice, according to which economic and social strategies of human behavior are explained primarily by rational choice. Instead, Inglehart articulates the fundamentally important idea that the presence of emotions is ultimately more rational than pure rationality. The logic of his reasoning is that it is feelings that enable people to make and fulfill long-term commitments. Pure rationality always suggests the prospect of the end in the case of achieving results and benefits. Instead, emotions allow people to implement certain ideas and projects beyond pure rationality (Inglehart 2018). In the context of this study, Inglehart's idea of emotional rationality is a powerful justification for the phenomenon of ecological values, because they are, by their nature, the result of understanding the relationship "Human being - Nature", which has a purely emotional essence. After all, there is an emotional basis in the formulated in this research ecological values, which are of fundamental importance in the context of professional training of future natural sciences teachers (in particular, the value of life in all its manifestations; nature as self-worth; the value of harmony with nature, etc.).

Among the available classifications of values, of particular interest to this research is the classification of the American researcher Ralph Perry, which is based on the category of "interest". It is interest that serves as a tool for singling out values. First, interest is the source of singling out values as something desirable. Secondly, interest is a criterion for dividing values into existential (which an individual experiences) and ideal (which appear to an individual as a goal). The main indicators in the gradation of values by Perry are correctness, intensity, and involvement (Perry 1950). According to Perry's approaches, the value of life in all its manifestations can be interpreted as an existential one, in turn, the value of harmony with nature - as the ideal personal goal.

In her research in the field of value-oriented education, the Ukrainian researcher Olha Molchaniuk identifies the following types of values: 1) intellectual values (knowledge, skills, abilities); 2) aesthetic values (a kind of the world perception according to the aesthetic criteria); 3) social values (needs conditioned by social existence); 4) allocentric values (value in the Kantian sense: that is valuable, which serves another person against own interests); 5) material values (utilitarian approach to the world around - that is valuable, which is useful); 6) hedonistic values (that is valuable, which brings pleasure); 7) emotional values (value is determined by emotional perception and emotional experiences); 8) values of improvement (that is valuable, which provides personal progress); 9) values of prestige (associated with the recognition and positive assessments of others) (Molchaniuk 2018). In turn, taking into account this classification, we consider it possible to distribute the potential environmental values of future natural sciences teachers to certain types described above, which will further show their diversity and their different directions (table 3). 
Table 3.

\section{Correlation of values classification according to $O$. Molchaniuk and conceptualized in this research ecological values, which are a basic concept for professional training of future natural sciences teachers}

\begin{tabular}{|c|c|c|c|}
\hline \multirow[t]{2}{*}{ \# } & \multicolumn{2}{|c|}{ Value according to 0 . Molchaniuk } & \multirow{2}{*}{$\begin{array}{c}\text { Ecological values in } \\
\text { professional training of } \\
\text { future teachers of } \\
\text { natural sciences }\end{array}$} \\
\hline & name & characteristics & \\
\hline 1 & intellectual values & (knowledge, skills, abilities) & $\begin{array}{l}\text { the value of environmental } \\
\text { knowledge }\end{array}$ \\
\hline 2 & aesthetic values & $\begin{array}{l}\text { a kind of the world perception } \\
\text { according to aesthetic criteria }\end{array}$ & ecological image as a value \\
\hline 3 & social values & $\begin{array}{l}\text { needs conditioned by social } \\
\text { existence }\end{array}$ & $\begin{array}{l}\text { the value of life in all its } \\
\text { manifestations }\end{array}$ \\
\hline 4 & allocentric values & $\begin{array}{l}\text { value in the Kantian sense: that is } \\
\text { valuable, which serves another } \\
\text { person against own interests }\end{array}$ & $\begin{array}{l}\text { biocentrism as a responsibility } \\
\text { for the world of living beings }\end{array}$ \\
\hline 5 & material values & $\begin{array}{l}\text { utilitarian approach to the world } \\
\text { around - that is valuable, which is } \\
\text { useful }\end{array}$ & $\begin{array}{l}\text { rejection of the utilitarian } \\
\text { approach to nature }\end{array}$ \\
\hline 6 & hedonistic values & $\begin{array}{l}\text { that is valuable, which brings } \\
\text { pleasure }\end{array}$ & $\begin{array}{l}\text { healthy environment as a } \\
\text { value }\end{array}$ \\
\hline 7 & emotional values & $\begin{array}{l}\text { value is determined by emotional } \\
\text { perception and emotional } \\
\text { experiences }\end{array}$ & $\begin{array}{l}\text { the value of harmony with } \\
\text { nature }\end{array}$ \\
\hline 8 & values of improvement & $\begin{array}{l}\text { that is valuable, which provides } \\
\text { personal progress }\end{array}$ & self-worth of nature \\
\hline 9 & values of prestige & $\begin{array}{l}\text { associated with the recognition } \\
\text { and positive assessments of others }\end{array}$ & the value of quality of life \\
\hline
\end{tabular}

* - author's own development

\section{Discussion}

Based on the analysis of scientific studies of Ukrainian (A. Kramarenko, O. Mamonova, O. Matviichuk, O. Molchaniuk, I. Sosunova) and foreign (M. Rokeach, R. Inglehart, A. Maslow, S. Schwartz, Ch. Morris, R. Perry, etc.) we consider it possible to suggest own conception of ecological values. We interpret them as a source of behavioral motivation and a regulator of the activities of an individual and society in the context of the relationship "Human being - Nature". Ecological values can be divided into (1) values of terminal-positional nature and (2) values of instrumental-behavioral nature. The specificity of ecological values is that they have an existential depth, materialist and post-materialist dimensions, and correspond to the global trend of widespread values of self-expression. The idea of emotional rationality of Inglehart is a powerful substantiation of the phenomenon of ecological values, because they are, by their nature, a consequence of understanding the relationship "Human being - Nature", which has an exclusively emotional character. After all, there is an the emotional basis in the formulated by us ecological values, which are of fundamental importance in the context of professional training of future natural sciences teachers: 1) the value of life in all its manifestations; 2) self-worth of nature; 3 ) the value of harmony with nature; 4) biocentrism as a responsibility for the world of living beings; 5) a healthy environment as a value; 6) the value of quality of life (in ecological discourse); 7) the value of environmental knowledge; 8) ecological image as a value. The given list of 
ecological values of future teachers of natural sciences proves their diverse and multidirectional character.

In addition, we consider it necessary to provide a meaningful description of the ecological values formulated by us for future natural sciences teachers.

1. The value of life in all its manifestations. This value is based on the recognition of the fact of the sacred inviolability of life, the primacy of its value in relation to other values, because life is being itself. "I am a life that wants to live; I am a life among life that wants to live" (Schweitzer 1973, 306).

2. Self-worth of nature. The decisive factor here is the recognition of nature as a space for the unfolding of life in all its diversity. For a human being, nature is the existential basis and prerequisite for individual self-fulfillment and self-improvement, as well as for social progress and development. After all, nature embodies goodness, truth and beauty, which is also the basis for recognizing its value.

3. The value of harmony with nature. The connection between a human being and nature, society and nature is indisputable. Given this, the lack of harmony in the relationship "Human being - Nature", as we have shown, leads to destructive consequences for both sides of this relationship. The human soul and body are rooted in nature and this is why nature is valuable.

4. Biocentrism as a responsibility for the world of living beings. Fundamental to biocentrism is the recognition of the primacy of the interests of the ecosphere over the interests of human beings. Biocentrism is genetically linked to the fundamental idea of not harming all living things. On the other hand, biocentrism focuses on balanced, future-oriented environmental solutions.

5. A healthy environment as a value. A healthy environment is the main prerequisite for a person's health and, generally speaking, life. Recognition of the value of a healthy environment corresponds to the strategy and content of the development of an individual and humanity in general. This value is relevant due to the fact that the well-being of the society is associated with a certain quality of the environment. Changes in these qualities for an individual and humanity can turn into a catastrophe.

6 . The value of quality of life (in ecological discourse). This value is related to the previous one. Quality life (concerning environment) is desirable and to some extent prestigious. Today, people are willing to pay significant sums for ecological quality of life (living conditions, food, clothing), which proves the relevance of this value in the value system of a modern individual.

7. The value of environmental knowledge. It comes from the recognition of the selfworth of nature and the value of harmony with nature. The implementation of these values obviously requires special training, certain competencies, the provision of which is possible via the acquisition of environmental knowledge. In addition, understanding of the content of environmental knowledge necessarily projects our reasoning into the ethical dimension of the relationship "Human being - Nature".

8. Ecological image as a value. The ability to make a positive impression on others has always been valued. In today's world, the ecological image is obviously a positive one, as it is associated with environmental safety, environmental rationality, minimizing of environmental risks and promoting the harmonization of the relationship "Human being - Nature". Ecological image is now a fashionable image, and everything connected with it has a positive character and perception. 


\section{Conclusions}

Summarizing the results of conceptualization of the phenomenon of ecological values as a basic concept for professional training of future natural sciences teachers, we can state the following:

1. Nowadays, many pedagogical studies focus on identifying factors and mechanisms, finding methods and developing effective technics that ensure full implementation of ecological goals of higher education. On the other hand, the search for methods of environmental knowledge implementation and provisions of environmental ethics in specific professional contexts continues with the development of appropriate competencies that correlate with the profile of the specialty (profession).

2. Based on the conducted analysis, we interpret ecological values as a source of behavioral motivation and a regulator of an individual and society in the context of the relationship "Human being - Nature". Ecological values can be reasonably divided into (1) values of terminal-positional nature and (2) values of instrumental-behavioral nature. The specificity of ecological values is that they have an existential depth, materialist and postmaterialist dimension, and correspond to the global trend of spreading values of selfexpression.

3. Ecological values of future natural sciences teachers appear as a single value block in the system of value orientations of an individual, consisting of different in meaning ecological values of individual and social nature, which are also different in their mechanisms of functioning and formation.

4. Formation of ecological values during the training of future natural sciences teachers obviously involves the use of the developments (theoretical and practical) of value education. However, the implementation of these developments requires a theoretical justification of the pedagogical model of ecological values formation of future natural sciences teachers. On the other hand, the facts of effective value education can certainly be confirmed by the development level of ecological values that motivate environmental behavior in all human activities, including professional.

\section{References}

Buhaiova, N. M. 2009. «Ekolohichnyy pidkhid yak peredumova emotsiynotsinnisnoho stavlennya do osobystosti». Aktualni problemy psykholohiyi. Vyp. 20:51-55.

Callicott, B. 2006. «Explicit and implicit values», The Endangered Species Act at Thirty: Conserving Biodiversity in Human-Dominated Landscapes. Vol. II. eds. J. Scott, D. Goble, \& F. Davis (Washington, DC: Island Press,): 36-48.

Callicott, B. 1989. In Defense of the Land Ethic: Essays in Environmental Philosophy. Albany, NY: State University Press of New York Press.

Chaika, H. V. 2015. «Tsinnisno-smyslova sfera u kryzovi periody rozvytku osobystosti». Aktualni problemy psykholohiyi. T. 9, Vyp. 6: 93-101.

Elliot, R. 1992. «Intrinsic value, environmental obligation, and naturalness». The Monist. $75: 138-160$.

Frankl, S. L. 1991. «Dukhovnyye osnovy obshchestva». Russkoye zarubezhye. Leningrad: Lenizdat, S. 243-433.

Hardashuk, T. V. 2005. Kontseptualni parametry ekolohizmu. Kyiv: Parapan.

Hofstede, G. 1980. Culture's consequences: International differences in work-related values. Beverly Hills, CA: Sage.

Inglehart, R. 2018. Kulturnaya evolyutsiya: kak menyayutsya chelovecheskiye motivatsii i kak eto menyayet mir. Moskva: Mysl.

Inglehart, R. 1997. Modernization and postmodernization: Cultural, economic, and political change in 43 societies. Princeton, NJ: Princeton University Press. 
Inglehart, R. 1977. The Silent Revolution: Changing Values and Political Styles Among Western Publics. Princeton University Press.

Inglehart, R., Baker, W. E. 2000. «Modernization, cultural change, and the persistence of traditional values». American Sociological Review. № 65: 19-51.

Inglehart, R., Welzel, C. 2010. «Changing mass priorities: The link between modernization and democracy». Reflections. № 8 (2): 551-567.

Jonas, H. 2001. Pryntsyp vidpovidalnosti. U poshukakh etyky dlya tekhnolohichnoyi, Kyyiv: Libra.

Kramarenko, A. M. 2015. «Formuvannya ekolohichnykh tsinnostey maybutnikh fakhivtsiv pochatkovoyi osvity $\mathrm{V}$ umovakh tsyvilizatsiynykh zmin: teoriya ta praktyka». Visnyk Natsionalnoyi akademiyi Derzhavnoyi prykordonnoyi sluzhby Ukrayiny. Vyp. 3. URL: http://www.irbis-nbuv.gov.ua/cgi-bin/irbis_nbuv/.

Leopold, A. 1983. Kalendar peschanogo grafstva. Moskva: Mir.

Matviichuk, A. V. 2014. Ekolohichna deontolohiya: filosofsko-metodolohichne osmyslennya naukovykh perspektyv: monohrafiya. Rivne: O. Zen.

Meyer-Abich, K. M. 2004. Povstannya na zakhyst pryrody. Vid dovkillya do spilnosvitu / per. z nim. A. Yermolenka. Kyiv: Libra.

Molchaniuk, O. V. 2018. «Zakonomirnosti ta principi vihovannya cinnisnogo stavlennya do prirodi maybunnih uchiteliv biologii». Teoriya i metodika profesiynoyi osviti. Vip. 14. URL : https://ivetscienceipto.wixsite.com/tmpo/kopiya-13-2017

Perry, Ralph Barton. 1950. General Theory of Value: Its Meaning and Basic Principles Construed in Terms of Interest. Harvard University press,

Pro vyshchu osvitu: Zakon Ukrayiny vid 1 lypnia 2014 roku № 1556-VII. https://zakon.rada.gov.ua/laws/show/1556-18.

Rockeach, M. 1973. The nature of Human Values. N.Y.: Free press.

Rohova, O. H. 2010. «Aksiolohichnyy aspekt humanitarnoyi paradyhmy osvity». Hrani. № 4 (72):56-59.

Rolston, H. III. 1986. Philosophy Gone Wild: Essays in Environmental Ethics. Amherst, NY: Prometheus.

Sandler, R. 2012. «Intrinsic Value, Ecology, and Conservation». Nature Education Knowledge. № 3(10):4.

Scheler, M. 1994. Izbrannyye proizvedeniya. Moskva: Gnozis.

Schwartz, S. H. 1992. «Universals in the content and structure of values: Theory and empirical tests in 20 countries». Advances in experimental social psychology. New York: Academic Press. Vol. 25: 1-65.

Schweitzer, A. 1973. Kultura i etika. Moskva: Progress.

Schweitzer, A. 1996. Zhizn i mysli. Moskva: Respublika.

Seed, J., Macy, J., Fleming, P., Naess, A. 1994. Dumaya kak gora: na puti k sovetu vsekh sushchestv. Moskva: «Sovetsko-amerikanskaya gumanitarnaya initsiativa Golubka».

Sosunova, I. A., Mamonova, O. N. 2018. «Sotsialno-ekologicheskiye tsennosti kak osnova novogo kachestva zhizni». Kachestvo i zhizn. № 4 (20): 151-158.

Soulé, M. E. 1985. «What is conservation biology?» Bioscience. 35, 727-734.

UN Climate Action Summit 2019. UNITED NATIONS. URL: https://www.un.org/en/climatechange/un-climate-summit2019.shtml?fbclid=IwAR1D3G_JMpbF4H_8BLKhiy4juaTnQ64e0MOYdAhBWaxiQqCauL FVuiPX7zM.

UNEP. 2012. 21 Issues for the 21st Century: Result of the UNEP Foresight Process on Emerging Environmental Issues. United Nations Environment Programme (UNEP). Nairobi, Kenya. 56 pp.

Vernadskiy, V. I. 1989. Biosfera i noosfera. Moskva: Nauka. 
Yanitskiy, M. S. 2012. Tsennostnoye izmereniye massovogo soznaniya. Novosibirsk: Izd-vo SO RAN. 